\title{
Unraveling the Dynamic Network in the Reactions of an Alkyl Aryl Ether Catalyzed by $\mathrm{Ni} / \gamma-\mathrm{Al}_{2} \mathrm{O}_{3}$ in 2-Propanol
}

\author{
Long Qi ${ }^{1,2,3}$ Ali Chamas, ${ }^{1}$ Zachary R. Jones, ${ }^{1}$ Eric D. Walter, ${ }^{4}$ David W. Hoyt, ${ }^{4}$ Nancy M. \\ Washton, ${ }^{4}$ Susannah L. Scott ${ }^{1,2 *}$ \\ ${ }^{1}$ Department of Chemistry \& Biochemistry, University of California, Santa Barbara, California 93106, USA \\ ${ }^{2}$ Department of Chemical Engineering, University of California, Santa Barbara, California 93106, USA \\ ${ }^{3}$ U.S. DOE Ames Laboratory, Iowa State University, Ames, Iowa 50011, USA. \\ ${ }^{4}$ Environmental Molecular Sciences Laboratory, Pacific Northwest National Laboratory, Richland, WA 99354 , \\ USA \\ *Correspondence to: sscott@ucsb.edu
}

Table of Contents Page

$\begin{array}{ll}\text { Characterization of } \mathrm{Ni} / \gamma-\mathrm{Al}_{2} \mathrm{O}_{3} & \mathrm{~S} 2\end{array}$

Table S1 Properties of Ni nanoparticles supported on $\gamma-\mathrm{Al}_{2} \mathrm{O}_{3} \quad$ S3

Table S2 XPS binding energies $\quad$ S3

Figure S1 Temperature evolution of 2-PrOH chemical shifts $\quad$ S4

Figure S2 $\quad{ }^{13} \mathrm{C}$ MAS-NMR spectra of ${ }^{13} \mathrm{C}$-labeled BPE in 2-PrOH $\quad$ S5

Figure S3 Operando ${ }^{13} \mathrm{C}$ MAS-NMR spectra recorded during the reaction of BPE at $150{ }^{\circ} \mathrm{C} \quad \mathrm{S} 6$

Figure S4 Comparison of reaction rates for BPE conversion with variable $\mathrm{H}_{2}$ pressure at $\quad \mathrm{S} 7$ $150{ }^{\circ} \mathrm{C}$

Figure S5 $\quad{ }^{1} \mathrm{H}$ MAS-NMR spectra, recorded at $25^{\circ} \mathrm{C}$, before and after BPE hydrogenolysis $\quad$ S8 catalyzed by $\mathrm{Ni} / \gamma-\mathrm{Al}_{2} \mathrm{O}_{3}$ at $150{ }^{\circ} \mathrm{C}$

Figure S6 First-order curvefits of kinetic profiles and pseudo-first-order rate constants for $\quad$ S9

Figure $\mathbf{S 7}$ Operando ${ }^{13} \mathrm{C}$ MAS-NMR spectra recorded during BPE hydrogenolysis in 2- $\quad$ S10

Figure S8 Solution-state ${ }^{13} \mathrm{C}$ NMR spectra of 2-PrOH- $d_{0}, 2-\mathrm{PrOD}-d_{1}$, and their mixture $\quad \mathrm{S} 11$

Figure S9 Kinetic profiles for BPE conversion at $175^{\circ} \mathrm{C}$ in 2-PrOH- $d_{0}$ with $\mathrm{D}_{2}$ catalyzed by $\mathrm{S} 12$

$2 \mathrm{wt} \% \mathrm{Ni} / \gamma-\mathrm{Al}_{2} \mathrm{O}_{3}$, showing $\mathrm{H} / \mathrm{D}$ exchange profiles

Figure S10 $\quad{ }^{13} \mathrm{C}$ MAS-NMR spectra recorded at $25{ }^{\circ} \mathrm{C}$ after reaction of ${ }^{13} \mathrm{C}$-labeled BPE in 2- $\quad \mathrm{S} 13$

PrOD- $d_{8}$ with $\mathrm{H}_{2}$ over $\mathrm{Ni} / \gamma-\mathrm{Al}_{2} \mathrm{O}_{3}$

$\begin{array}{lll}\text { Table S3 } & { }^{13} \mathrm{C} \text { chemical shifts for isotopically-labeled toluenes in 2-PrOD- } d_{8} & \mathrm{~S} 14\end{array}$

Figure S11 Mass spectrum of toluene from hydrogenolysis of BPE in 2-propanol- $d_{8} \quad S 14$

Figure S12 Operando ${ }^{13} \mathrm{C}$ MAS-NMR spectra of toluene- $\alpha-{ }^{13} \mathrm{C}$ in 2 -PrOH- $d_{0}$ recorded during $\quad \mathrm{S} 15$

$\mathrm{H} / \mathrm{D}$ exchange with $\mathrm{D}_{2}$ catalyzed by $\mathrm{Ni} / \gamma-\mathrm{Al}_{2} \mathrm{O}_{3}$ at $150{ }^{\circ} \mathrm{C}$

Figure S13 Powder X-ray diffraction of $\mathrm{Ni} / \gamma-\mathrm{Al}_{2} \mathrm{O}_{3} \quad \mathrm{~S} 16$

Figure S14 Portions of the EPR spectra of $\mathrm{Ni} / \gamma-\mathrm{Al}_{2} \mathrm{O}_{3}$, before and after reduction by $\mathrm{H}_{2} \quad \mathrm{~S} 16$

$\begin{array}{lll}\text { Figure S15 High resolution XPS of } \mathrm{Ni} / \gamma-\mathrm{Al}_{2} \mathrm{O}_{3} & \mathrm{~S} 17\end{array}$

Figure S16 High angle annular dark field scanning transmission electron microscopy and $\quad$ S17 energy dispersive $\mathrm{X}$-ray (EDX) spectroscopy of $\mathrm{Ni} / \gamma-\mathrm{Al}_{2} \mathrm{O}_{3}$

Figure S17 Temperature programmed reduction of air-exposed $\mathrm{Ni} / \gamma-\mathrm{Al}_{2} \mathrm{O}_{3} \quad \mathrm{~S} 18$

$\begin{array}{lll}\text { Figure S18 Reaction profiles for BPE hydrogenolysis at } 150{ }^{\circ} \mathrm{C} \text { using non-air exposed } \mathrm{Ni} / \gamma- & \mathrm{S} 19\end{array}$

$\mathrm{Al}_{2} \mathrm{O}_{3}$

Figure S19 Solution-state NMR spectra of ${ }^{13}$ C-labeled BPE, recorded in DMSO- $d_{6} \quad$ S20

$\begin{array}{ll}\text { Additional References } & \text { S21 }\end{array}$ 


\section{Characterization of $\mathrm{Ni} / \boldsymbol{\gamma}-\mathrm{Al}_{2} \mathrm{O}_{3}$}

Elemental analysis by ICP-AES was conducted on a Thermo Model iCAP 6300 instrument. The catalyst $(50.0 \mathrm{mg})$ was digested overnight in $2.4 \mathrm{~mL}$ aqua regia $(3: 1 \mathrm{v} / \mathrm{v} \mathrm{HCl:HNO})$ at $80{ }^{\circ} \mathrm{C}$, then diluted to $20 \mathrm{~mL}$ with deionized water. Calibration curves were constructed with four solutions $(0.1,1,10$, and $100 \mathrm{ppm})$ prepared by diluting a standard solution (Inorganic Ventures, $1000 \mathrm{ppm}$ $\mathrm{Ni}$ in $2 \% \mathrm{HNO}_{3}$ ). Data were processed with the software iTEVA.

The accessible metal surface area was determined by selective oxidation of surface Ni atoms with $\mathrm{N}_{2} \mathrm{O}$, followed by titration with $\mathrm{H}_{2},{ }^{1}$ using a Micrometrics Autochem ii 2920. A U-shaped quartz reactor was packed with a plug of quartz wool which supported a catalyst bed of $110 \mathrm{mg}$. A thermocouple was attached to the outside of the reactor, at the level of the middle of the bed. The temperature was ramped to $300{ }^{\circ} \mathrm{C}$ at $10{ }^{\circ} \mathrm{C} \mathrm{min}-1$ under flowing Ar. After holding at $300{ }^{\circ} \mathrm{C}$ for 1 $\mathrm{h}$, the reactor was cooled to room temperature under flowing Ar. The catalyst was then heated in $\mathrm{H}_{2} / \mathrm{Ar}(10 \mathrm{vol} \%)$ to $850{ }^{\circ} \mathrm{C}$ at a ramp rate of $10{ }^{\circ} \mathrm{C} \mathrm{min}-1$, and was held at $850{ }^{\circ} \mathrm{C}$ for $2 \mathrm{~h}$ before cooling to room temperature under flowing He. The reduced material was heated in flowing $\mathrm{N}_{2} \mathrm{O}$ (9.99 vol\% in $\mathrm{He}$ ) at $60^{\circ} \mathrm{C}$ for $45 \mathrm{~min}$ to oxidize surface Ni atoms, eq $\mathrm{S} 1$. The Ni surface area was then determined by the $\mathrm{H}_{2}$ uptake during temperature-programmed reduction (TPR), eq S2.

$$
\begin{aligned}
& \mathrm{Ni}(0)+\mathrm{N}_{2} \mathrm{O} \rightarrow \mathrm{NiO}+\mathrm{N}_{2} \\
& \mathrm{NiO}+\mathrm{H}_{2} \rightarrow \mathrm{Ni}(0)+\mathrm{H}_{2} \mathrm{O}
\end{aligned}
$$

The metal surface area, $\mathrm{SA}_{\mathrm{Ni}}\left(\mathrm{m}^{2} \mathrm{~g}_{\mathrm{Ni}}{ }^{-1}\right)$, estimated nanoparticle size, $d_{\mathrm{Ni}}(\mathrm{nm})$, and $\mathrm{Ni}$ dispersion, $D_{\mathrm{Ni}}(\%)$, were calculated using eq S3-S5, assuming spherical Ni nanoparticles.

$$
\begin{aligned}
& S A_{N i}\left(m^{2} g_{N i}{ }^{-1}\right)=\frac{n_{H_{2}} N_{A} S F}{m_{c a t} W_{N i} A_{N i}} \\
& d_{N i}(n m)=\frac{6 \times 10^{3}}{S A_{N i} \rho_{N i}} \\
& D_{N i}(\%)=\frac{n_{H_{2}} M_{N i} S F}{W_{N i} m_{c a t}} \times 100 \%
\end{aligned}
$$

Here, $n_{\mathrm{H} 2}$ is the amount of $\mathrm{H}_{2}$ consumed, $\mathrm{N}_{\mathrm{A}}$ is Avogadro's number, SF is the stoichiometric coefficient of $\mathrm{H}_{2}$ in eq $\mathrm{S} 2, m_{\text {cat }}$ is the mass of catalyst, $\mathrm{W}_{\mathrm{Ni}}$ is the weight fraction of $\mathrm{Ni}$ determined by ICP (i.e., $1.9 \%$ or $10.5 \%$ ), $\mathrm{A}_{\mathrm{Ni}}$ is the areal density of metallic $\mathrm{Ni}, 1.54 \times 10^{19}$ atoms $\mathrm{m}^{-2}, \rho_{\mathrm{Ni}}$ is the bulk Ni density, $8.90 \mathrm{~g} \mathrm{~cm}^{-3}$, and $\mathrm{M}_{\mathrm{Ni}}$ is the atomic mass of $\mathrm{Ni}$. The catalyst containing ca. 2 $\mathrm{wt} \% \mathrm{Ni}$ has a metal surface area of $48 \mathrm{~m}^{2} \mathrm{gNi}^{-1}$. Based on the total metal content, this surface area corresponds to $14 \mathrm{~nm}$ particles (Table S1). However, the material contains ca. $55 \% \mathrm{Ni}(0)$ and 45 $\%$ residual $\mathrm{Ni}^{2+}$, according to $\mathrm{H}_{2}$ uptake during reduction of the calcined catalyst precursor (see main text). The dispersion (surface $\mathrm{Ni}(0)$ sites) represents ca. $7 \%$ of the total Ni content. The catalyst containing $10 \mathrm{wt} \% \mathrm{Ni}$ has a similar metal surface area, $46 \mathrm{~m}^{2} \mathrm{~g} \mathrm{Ni}^{-1}$, corresponding to 15 nm particles and ca. $7 \%$ dispersion based on total Ni content.

The powder X-ray diffraction (XRD) pattern of $\mathrm{Ni} / \gamma-\mathrm{Al}_{2} \mathrm{O}_{3}$ was collected on a Philips X'PERT MPD, using $\mathrm{Cu} \mathrm{K} \mathrm{K}_{\alpha}(1.5405 \AA$ ) radiation. The diffractogram was indexed using the X'PERT High Score software package. It shows three new, broad reflections at $2 \theta=44.4,51.9,76.9$ and $93.1^{\circ}$, in addition to the expected reflections for $\gamma-\mathrm{Al}_{2} \mathrm{O}_{3}$ (see Figure $\mathrm{S} 13$ ). The latter are shifted slightly 
to lower angles relative to unmodified $\gamma-\mathrm{Al}_{2} \mathrm{O}_{3}$, presumably because of the presence of residual $\mathrm{Ni}^{2+}$ in the latttice. The new reflections were indexed to metallic Ni with a cubic close-packed structure in the $F m 3 m$ space group. ${ }^{2}$ The peak widths suggest that the Ni nanoparticles are ca. 20 $\mathrm{nm}$ in diameter.

Table S1. Properties of Ni nanoparticles supported on $\gamma-\mathrm{Al}_{2} \mathrm{O}_{3}$

\begin{tabular}{cccc}
\hline Ni Loading & Ni surface area $\left(\mathrm{m}^{2} \mathrm{~g}_{\mathrm{Ni}^{-1}}\right)$ & Average particle size $(\mathrm{nm})^{\mathrm{a}}$ & Ni dispersion $(\%)$ \\
\hline $2 \mathrm{wt} \%$ & $47.7(4)$ & $14.1(1)$ & $7.2(1)$ \\
$10 \mathrm{wt} \%$ & $45.8(9)$ & $14.7(3)$ & $6.9(2)$ \\
\hline
\end{tabular}

${ }^{\text {a }}$ Estimated from the measured $\mathrm{Ni}(0)$ surface area.

X-ray photoelectron spectroscopy (XPS) was performed on a Kratos Ultra system equipped with an Al-K $\alpha(1559 \mathrm{eV})$ radiation source. Prior to data collection, a baseline vacuum of $1 \times 10^{-8}$ Torr was achieved. High resolution scans were acquired with a band pass energy of $40 \mathrm{eV}$. Binding energies were calibrated using the $1 \mathrm{~s}$ peak of adventitious carbon at $284.6 \mathrm{eV}$. Deconvolution of the Ni $2 p_{3 / 2}$ region was performed using the Casa XPS software package. The calcined catalyst precursor shows a well-defined $2 p_{3 / 2}$ peak at $855.8 \mathrm{eV}$, with a small contribution at $857.8 \mathrm{eV}$ (Figure S15a). These peak positions are consistent with the presence of $\mathrm{NiO}$ (major component) and $\mathrm{NiAl}_{2} \mathrm{O}_{4}$ (minor component), respectively. ${ }^{3-4}$ The broad feature at $862.1 \mathrm{eV}$ is a result of the multi-electron shake-up process that is observed only for cationic nickel. After high temperature $\mathrm{H}_{2}$ reduction, a new feature appeared at $852.4 \mathrm{eV}$, corresponding to a metallic Ni phase (Figure $\mathrm{S} 15 \mathrm{~b}$ ). It persisted despite air exposure of the sample. ${ }^{5}$ Peak positions and assignments are summarized in Table S2. The signal-to-noise ratio in the Ni $2 p$ region of the spectrum is much lower for the reduced catalyst compared to the spectrum of the calcined catalyst precursor. This is likely a result of overcoating by $\gamma-\mathrm{Al}_{2} \mathrm{O}_{3}$, which is known to occur during the extrusion of $\mathrm{Ni}$ nanoparticles. ${ }^{6}$

Table S2. XPS binding energies in the Ni $2 p$ region $(\mathrm{eV})$

\begin{tabular}{|c|c|c|c|c|c|c|}
\hline \multirow[t]{2}{*}{ Material } & \multicolumn{3}{|c|}{$2 p_{3 / 2}$} & \multirow[t]{2}{*}{ Satellite } & \multirow[t]{2}{*}{$2 p_{1 / 2}$} & \multirow[t]{2}{*}{ Satellite } \\
\hline & $\mathrm{Ni}(0)$ & $\mathrm{NiO}$ & $\mathrm{NiAl}_{2} \mathrm{O}_{4}$ & & & \\
\hline $\begin{array}{l}\text { Catalyst } \\
\text { precursor }\end{array}$ & - & 855.8 & 857.8 & 862.1 & 873.4 & 879.8 \\
\hline $\begin{array}{c}\mathrm{Ni} / \gamma-\mathrm{Al}_{2} \mathrm{O}_{3} \\
\text { (air-exposed) }\end{array}$ & 852.4 & 855.9 & n.d. & 861.9 & 873.2 & 880.3 \\
\hline
\end{tabular}

n.d. not detected.

To prepare a sample for transmission electron microscopy (TEM) imaging, the catalyst was first ground in a mortar with a pestle, then suspended in absolute ethanol and sonicated for $15 \mathrm{~min}$. The resulting suspension was drop-cast onto a $\mathrm{Cu}$-coated ultrathin carbon grid and allowed to dry in air for $15 \mathrm{~min}$ to allow the solvent to evaporate. High angle annular dark field scanning transmission electron microscopy (HAADF STEM) images were acquired on a FEI Tecnai G ${ }^{2}$ F20 $\mathrm{S}$-Twin field emission transmission electron microscope. EDX mapping shows evidence for Ni-Al 
segregation in the reduced $\mathrm{Ni}$ catalyst, and suggests the presence of a surface oxide on the metal nanoparticles (Figure S16).

Variable temperature EPR spectra of air-exposed $\mathrm{Ni} / \gamma-\mathrm{Al}_{2} \mathrm{O}_{3}$ were collected in a $4 \mathrm{~mm}$ OD quartz tube (Wilmad). In situ EPR spectra of reduced $\mathrm{Ni} / \gamma-\mathrm{Al}_{2} \mathrm{O}_{3}$ were acquired by immobilizing the sample in a $3 \mathrm{~mm}$ OD $\times 2 \mathrm{~mm}$ ID quartz tube with open ends with a plug of quartz wool on either side. This smaller tube was placed in a $5 \mathrm{~mm}$ OD EPR tube and the gas path controlled with a T-fitting such that the incoming gas flowed first down the space inside the $5 \mathrm{~mm}$ tube and outside the $3 \mathrm{~mm}$ tube, then turned and flowed over the sample inside the $3 \mathrm{~mm}$ tube and out to exhaust. This route was chosen so that when the assembly was placed in a variable temperature insert in the EPR resonator, the flowing gas equilibrated its temperature with that of the VT insert before entering the sample.

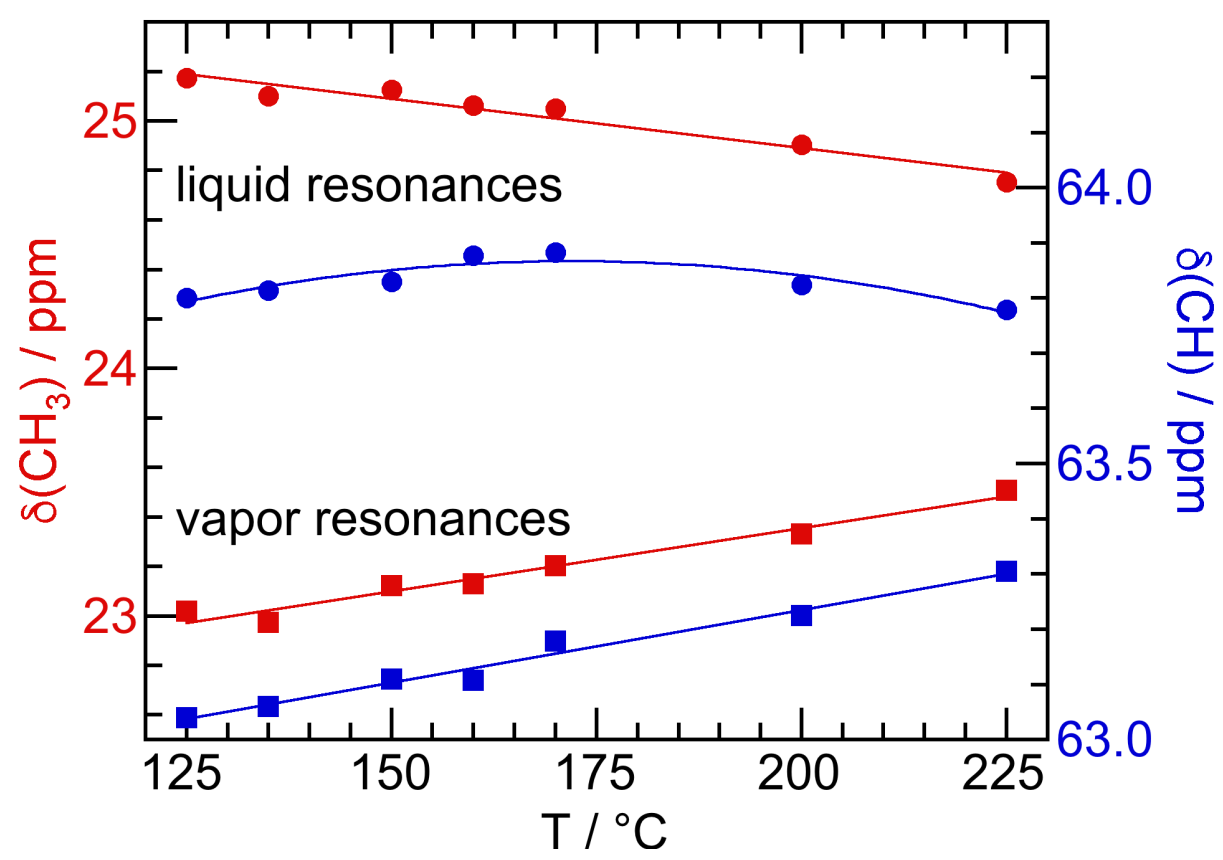

Figure S1. Temperature evolution of the methyl and methine resonances in both liquid (circles) and vapor (squares) phases of 2-PrOH sealed in a high T/P rotor, recorded by direct polarization ${ }^{13} \mathrm{C}$ MAS-NMR spectroscopy. The 5-mm o.d. NMR rotor (internal volume $140 \mu \mathrm{L}$ ) was charged with $40 \mu \mathrm{L} 2-\mathrm{PrOH}$ and 50 bar $\mathrm{H}_{2}$ at room temperature. Total internal pressures were estimated to range from 71 bar at $125^{\circ} \mathrm{C}$ to 118 bar at $225^{\circ} \mathrm{C}$. 


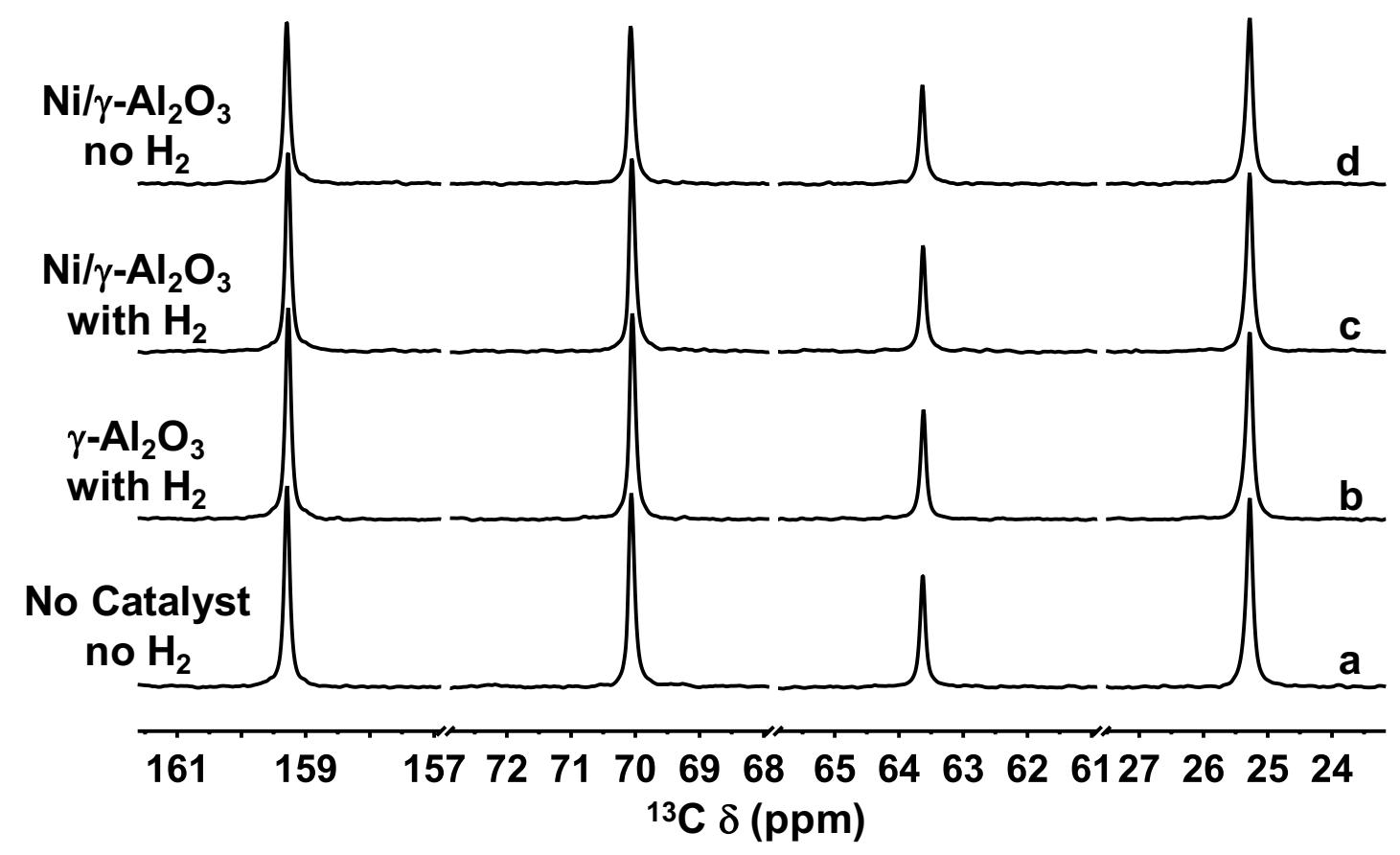

Figure S2. ${ }^{13} \mathrm{C}$ MAS-NMR spectra of ${ }^{13} \mathrm{C}$-labeled BPE in 2-PrOH, recorded at $25{ }^{\circ} \mathrm{C}$ : (a) without catalyst or $\mathrm{H}_{2}$; (b) with $\gamma-\mathrm{Al}_{2} \mathrm{O}_{3}(10 \mathrm{mg})$ and 50 bar $\mathrm{H}_{2}$; (c) with $2 \mathrm{wt} \% \mathrm{Ni} / \gamma-\mathrm{Al}_{2} \mathrm{O}_{3}(10 \mathrm{mg})$ and 50 bar $\mathrm{H}_{2}$ (estimated total internal pressure 79 bar at $150{ }^{\circ} \mathrm{C}$ ); and (d) with $2 \mathrm{wt} \% \mathrm{Ni} / \gamma-\mathrm{Al}_{2} \mathrm{O}_{3}(10 \mathrm{mg}$ ) but no $\mathrm{H}_{2}$. In all spectra, there is no apparent difference in either lineshape or chemical shift for any of the signals of BPE or 2-PrOH due to the presence of solids or $\mathrm{H}_{2}$. MAS rate: $5 \mathrm{kHz}$. 


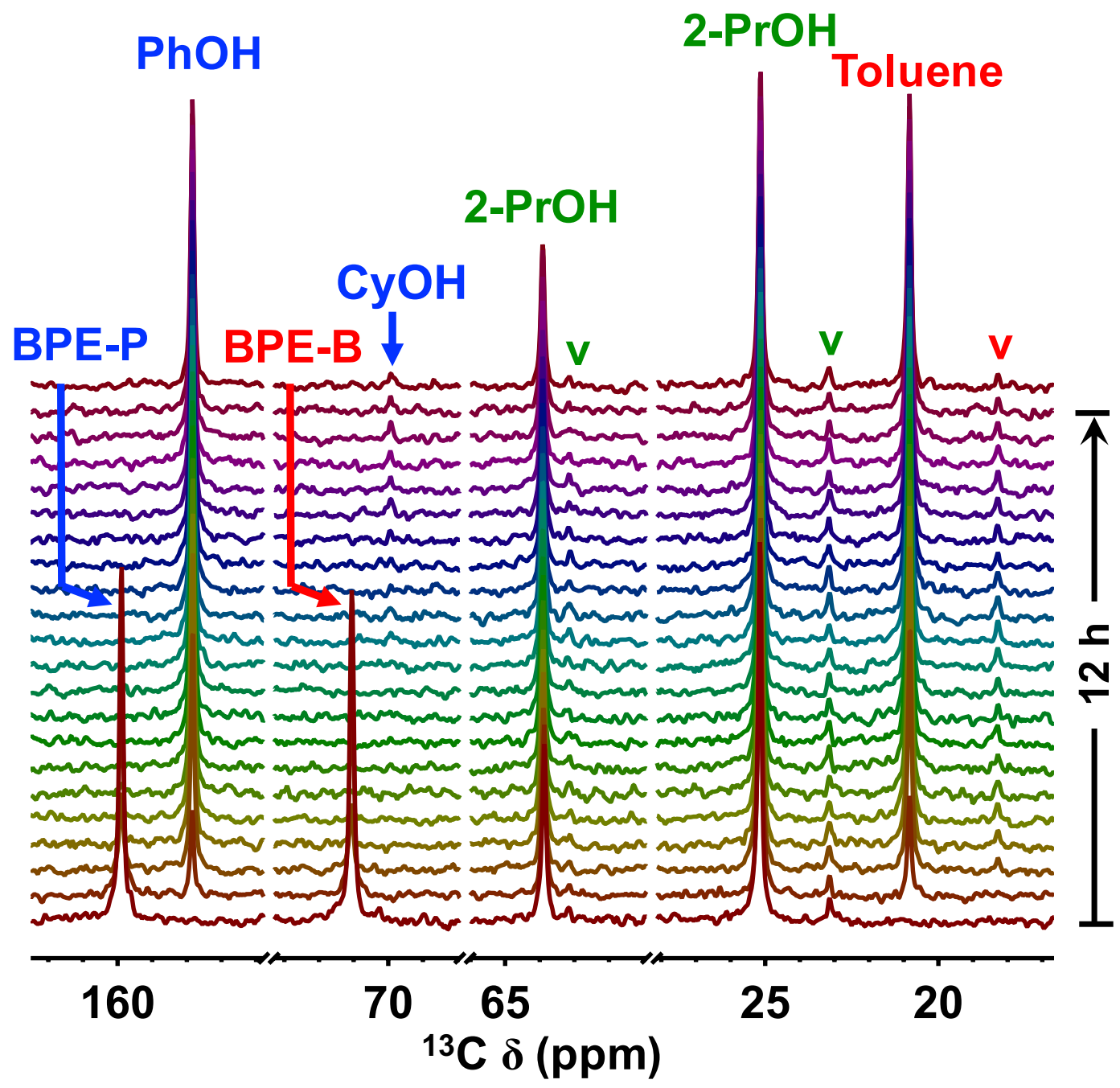

Figure S3. Operando ${ }^{13} \mathrm{C}$ MAS-NMR spectra recorded during the reaction of BPE $(2.0 \mathrm{mg}, 0.011$ mmol) in 2-PrOH (40 $\mu \mathrm{L}, 0.52 \mathrm{mmol})$ with 50 bar $\mathrm{H}_{2}(0.20 \mathrm{mmol})$, catalyzed by $2 \mathrm{wt} \% \mathrm{Ni} / \gamma_{-} \mathrm{Al}_{2} \mathrm{O}_{3}$ (10 mg, air-exposed) at $150{ }^{\circ} \mathrm{C}$, showing the formation of cyclohexanol $(\mathrm{CyOH})$ at extended reaction times. Each spectrum was acquired with 16 scans and a recycle delay of $60 \mathrm{~s}$. MAS rate: $5 \mathrm{kHz}$. Vapor phase signals are indicated by v. Estimated total internal pressure 79 bar at $150{ }^{\circ} \mathrm{C}$. 


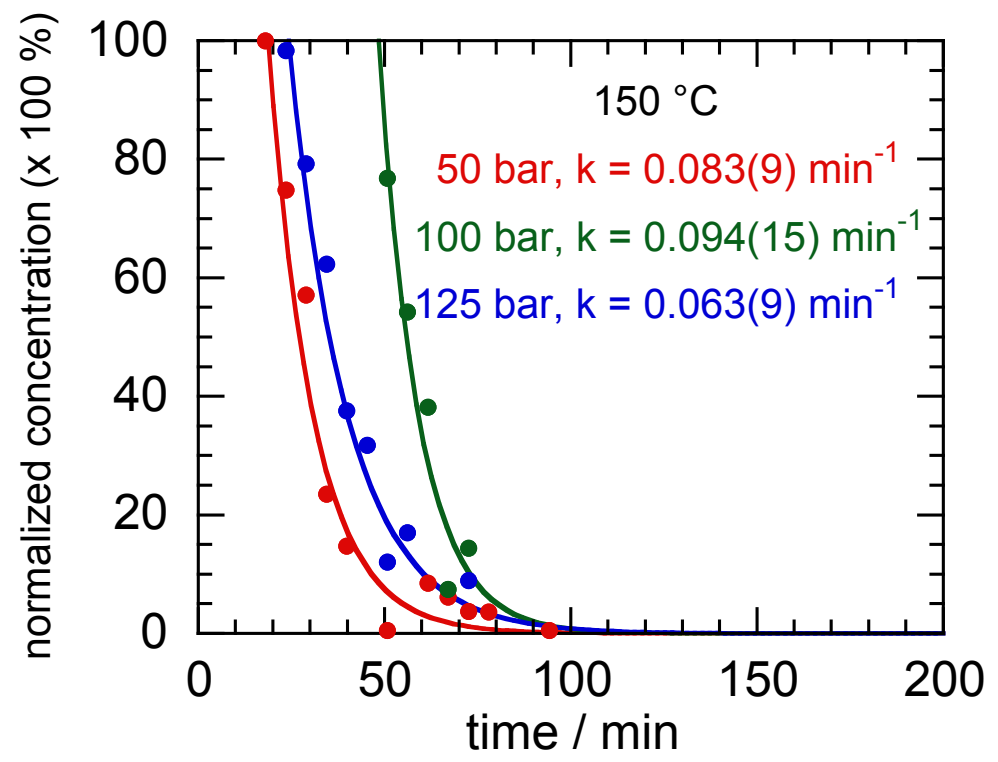

Figure S4. Comparison of reaction profiles for $\mathrm{BPE}$ conversion in 2-PrOH, catalyzed by $\mathrm{Ni} / \gamma-$ $\mathrm{Al}_{2} \mathrm{O}_{3}\left(2 \mathrm{wt} \%, \mathrm{H}_{2}\right.$-reduced then air-exposed) at $150{ }^{\circ} \mathrm{C}$, in a rotor charged with 50 (red), 100 (green), and 125 (blue) bar $\mathrm{H}_{2}$ (estimated total internal pressures: 79, 149, and 184 bar, respectively). Concentrations were calculated from the peak area of the $\mathrm{BPE}-\mathrm{B}{ }^{13} \mathrm{C}$ resonance at $70.1 \mathrm{ppm}$. Solid lines are non-linear least-squares curvefits to the first-order rate equation. Data collected during the induction period were removed prior to curvefitting. 


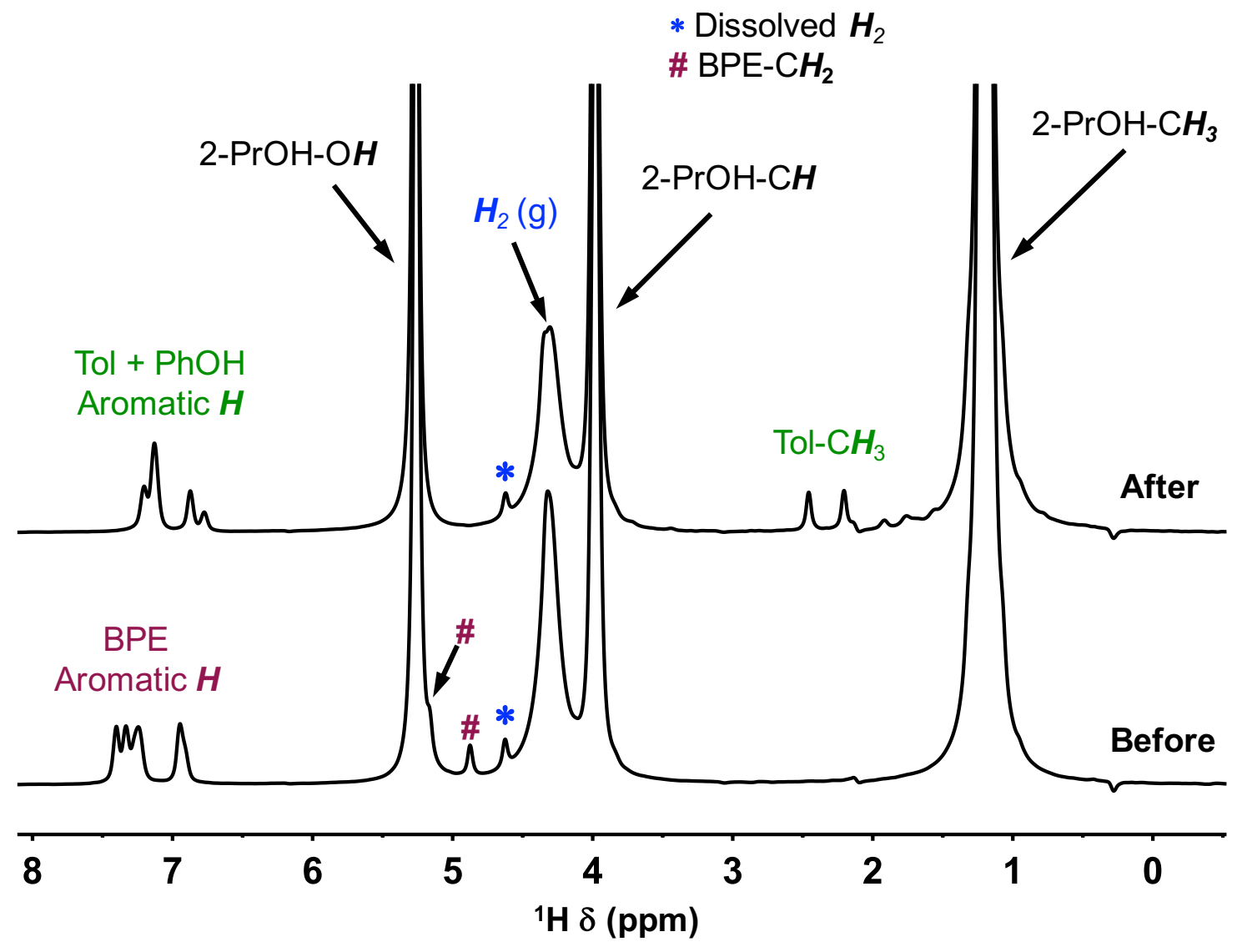

Figure S5. ${ }^{1} \mathrm{H}$ MAS-NMR spectra of ${ }^{13} \mathrm{C}$-labeled BPE $(2.0 \mathrm{mg}, 0.011 \mathrm{mmol})$ in 2-PrOH $(40 \mu \mathrm{L}$, $0.52 \mathrm{mmol})$ with 50 bar $\mathrm{H}_{2}(0.20 \mathrm{mmol})$ over $\mathrm{Ni} / \gamma-\mathrm{Al}_{2} \mathrm{O}_{3}(10 \mathrm{mg})$, recorded at $25^{\circ} \mathrm{C}$ before reaction at $150{ }^{\circ} \mathrm{C}$ for $10 \mathrm{~h}$ in a high $\mathrm{T} / \mathrm{P}$ rotor $(5 \mathrm{~mm}$ ), as well as after the reaction (and cooling the rotor to $25^{\circ} \mathrm{C}$ ). The total internal pressure was estimated to be 79 bar at $150{ }^{\circ} \mathrm{C}$. Spectra were collected by averaging 16 scans, with an acquisition time of $1 \mathrm{~s}$ and a relaxation delay of $10 \mathrm{~s}$. Line broadening of $15 \mathrm{~Hz}$ was applied. * and \# denote signals for dissolved $\mathrm{H}_{2}$ and BPE-methylene, respectively. 


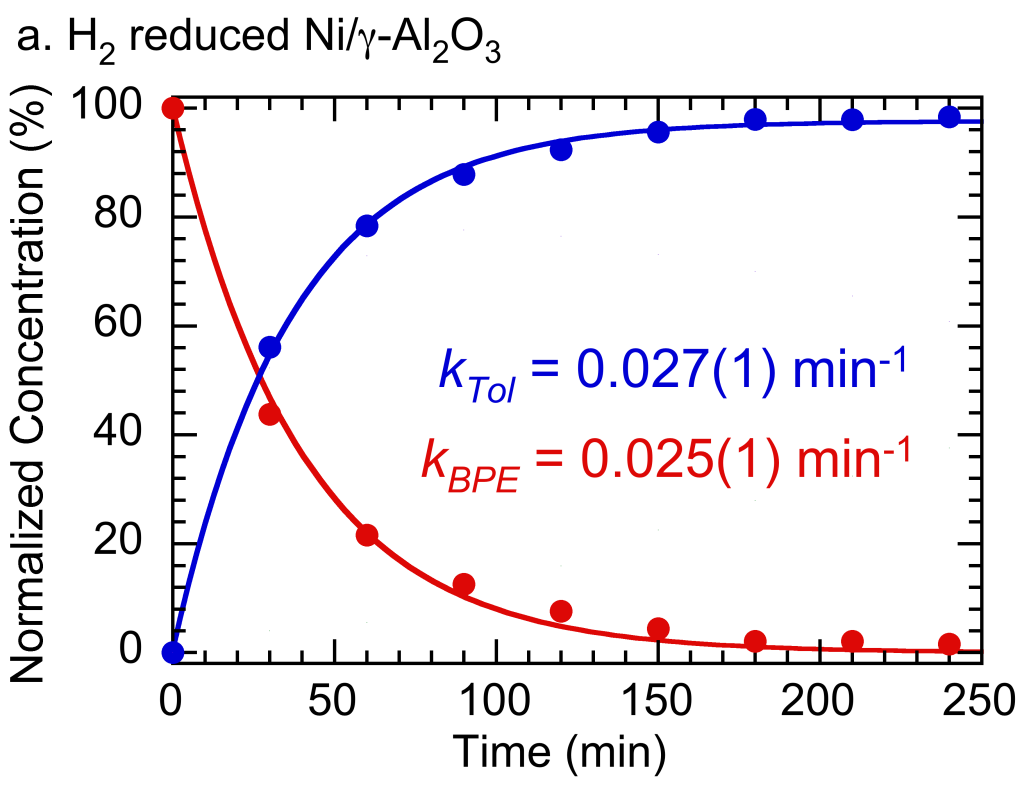

b. Air-exposed $\mathrm{Ni} / \gamma-\mathrm{Al}_{2} \mathrm{O}_{3}$

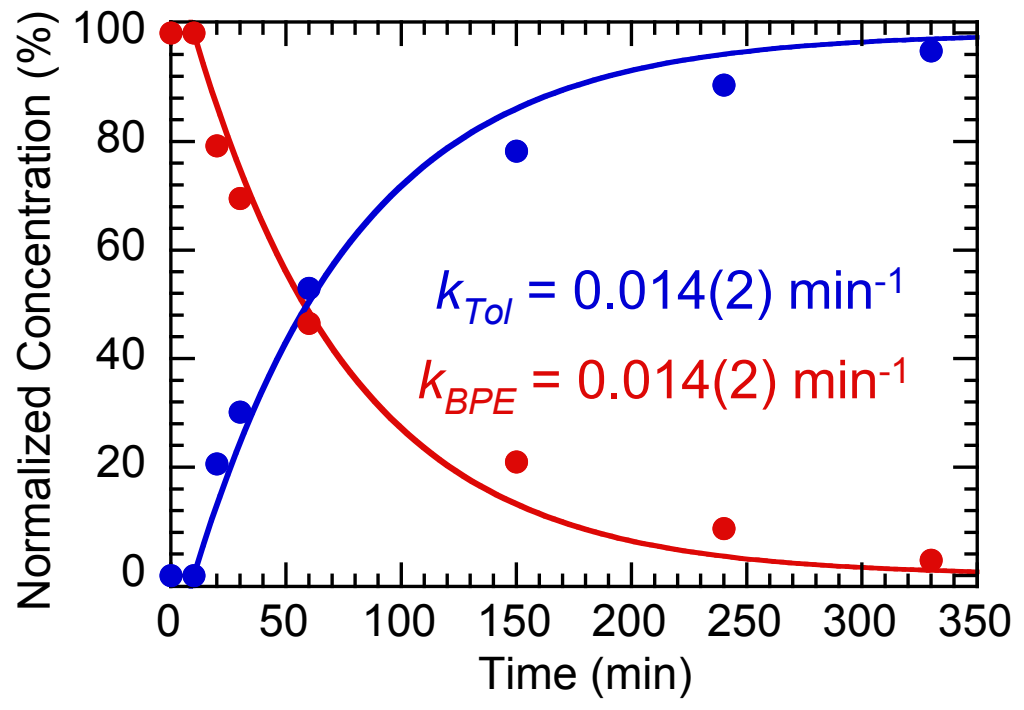

Figure S6. First-order curvefits of kinetic profiles and pseudo-first-order rate constants $\left(\mathrm{min}^{-1}\right)$ for conversion of BPE $(100 \mathrm{mg}, 0.54 \mathrm{mmol})$ and formation of toluene in 2-PrOH $(10 \mathrm{~mL})$, recorded in the presence of (a) $2 \mathrm{wt} \% \mathrm{Ni} / \gamma-\mathrm{Al}_{2} \mathrm{O}_{3}\left(500 \mathrm{mg}, \mathrm{H}_{2}\right.$-reduced), and (b) $2 \mathrm{wt} \% \mathrm{Ni} / \gamma-\mathrm{Al}_{2} \mathrm{O}_{3}(500$ $\mathrm{mg}$, air-exposed) with $50 \mathrm{bar} \mathrm{H}_{2}$ (total internal pressure estimated to be 79 bar at $150{ }^{\circ} \mathrm{C}$ ) in a 25 $\mathrm{mL}$ Parr batch reactor. The data shown represents aliquots withdrawn after the reactor temperature reached $150{ }^{\circ} \mathrm{C}$. The curvefits in (b) were performed excluding the first two data points, corresponding to the induction period. 


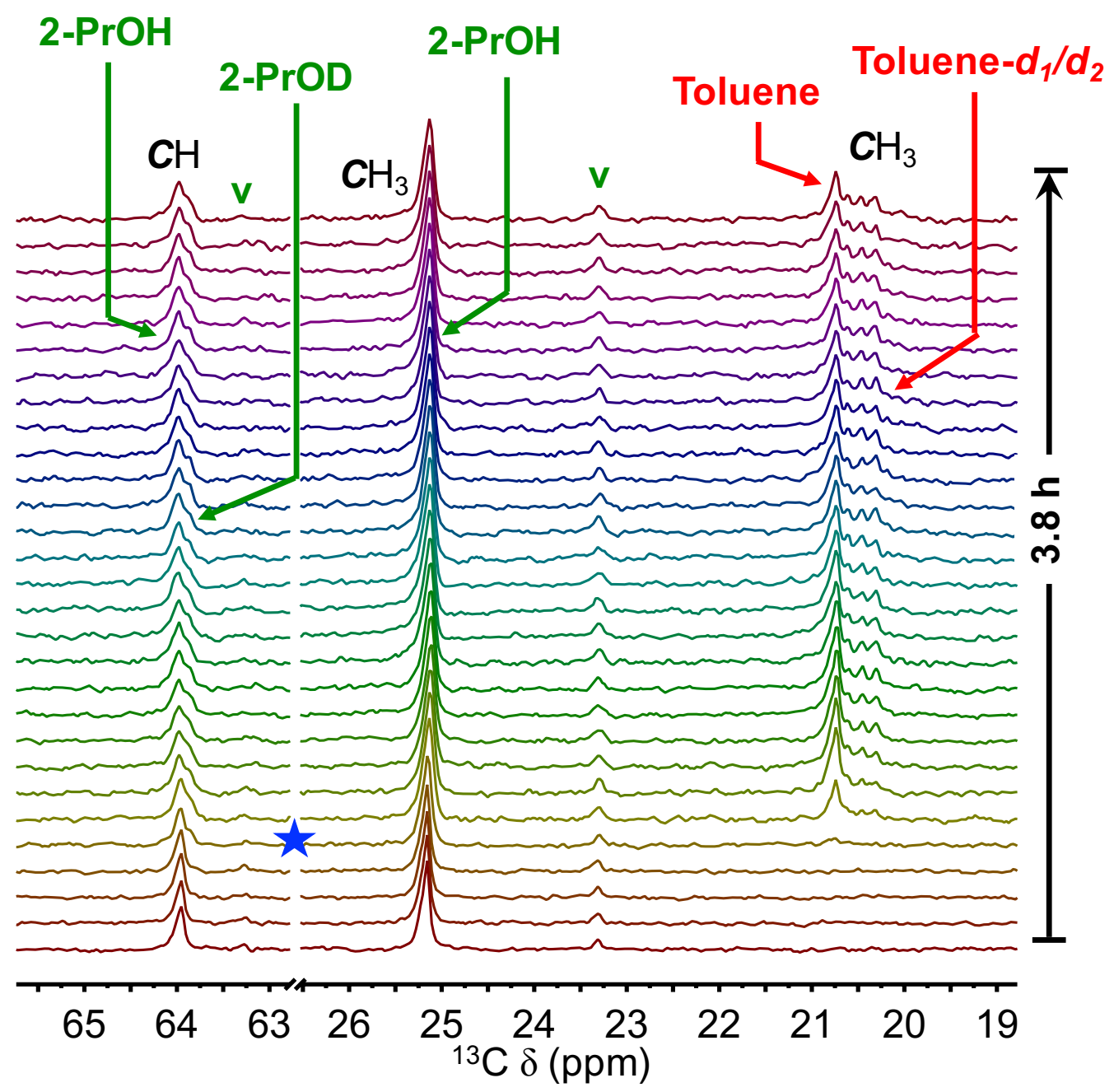

Figure S7. Operando ${ }^{13} \mathrm{C}$ MAS-NMR spectra recorded for BPE $(2.0 \mathrm{mg}, 0.011 \mathrm{mmol})$ in 2-PrOH $(40 \mu \mathrm{L}, 0.52 \mathrm{mmol})$ with 50 bar $\mathrm{D}_{2}(0.20 \mathrm{mmol})$ catalyzed by air-exposed $2 \mathrm{wt} \% \mathrm{Ni} / \gamma-\mathrm{Al}_{2} \mathrm{O}_{3}(10$ $\mathrm{mg}$ ) at $175{ }^{\circ} \mathrm{C}$, emphasizing the methine and methyl resonances of 2-PrOH, and the methyl resonance of toluene. Total internal pressure estimated to be 89 bar at $175^{\circ} \mathrm{C}$. $\star$ denotes the first spectrum at which onset of $\mathrm{H} / \mathrm{D}$ exchange in 2-PrOH becomes visible. Each spectrum was acquired with 16 scans and a recycle delay of $60 \mathrm{~s}$. MAS rate: $5 \mathrm{kHz}$. 


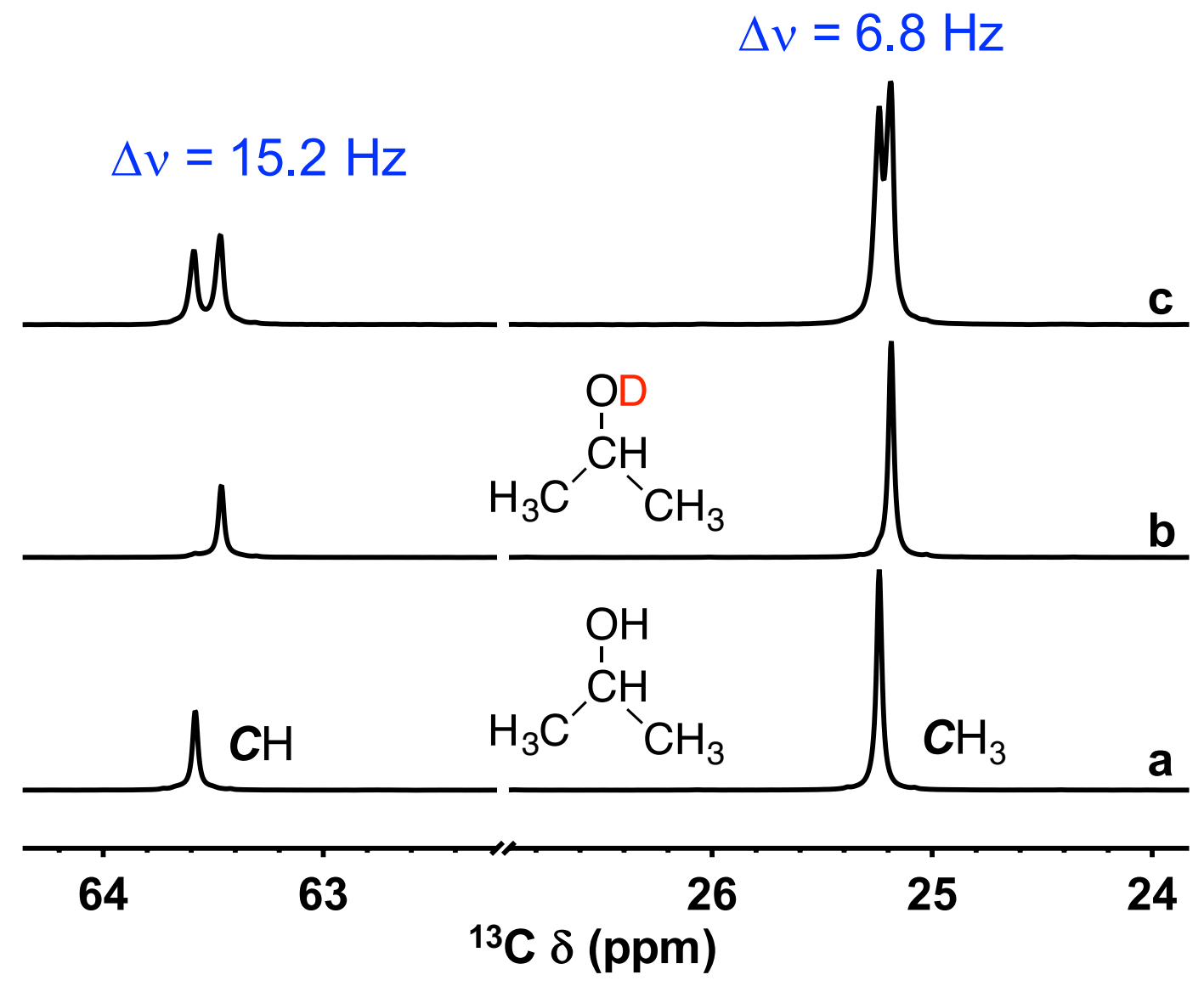

Figure S8. Solution-state ${ }^{13} \mathrm{C}$ NMR spectra of (a) 2-PrOH, (b) 2-PrOD- $d_{1}$, and (c) an approx. equimolar mixture of $2-\mathrm{PrOH}$ and $2-\mathrm{PrOD}-d_{1}$, all recorded at room temperature. 


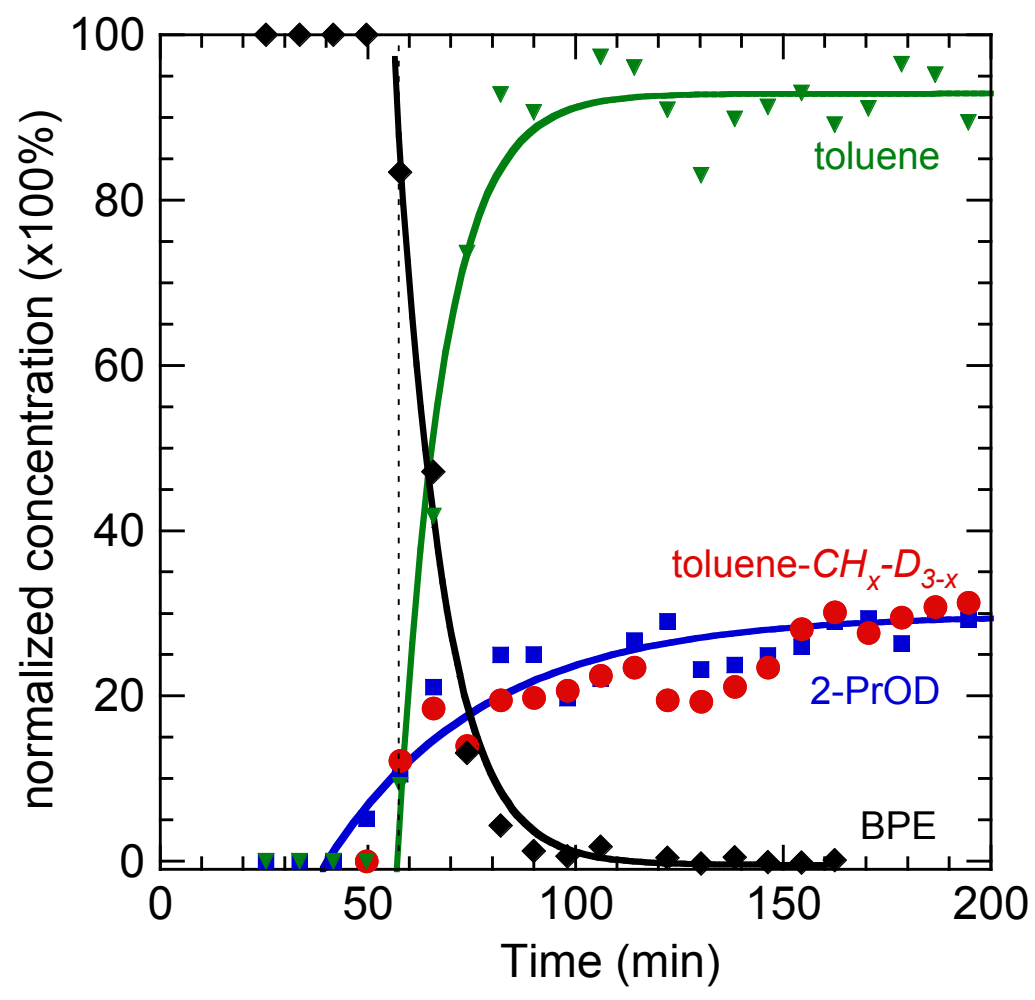

Figure S9. Kinetic profiles for the conversion of BPE $(2.0 \mathrm{mg}, 0.011 \mathrm{mmol})$ at $175^{\circ} \mathrm{C}$ in $2-\mathrm{PrOH}$ $\left(40 \mu \mathrm{L}\right.$ ) with 50 bar $\mathrm{D}_{2}$ (total internal pressure estimated to be 89 bar at $175^{\circ} \mathrm{C}$ ) and air-exposed 2 wt $\% \mathrm{Ni} / \gamma-\mathrm{Al}_{2} \mathrm{O}_{3}(10 \mathrm{mg})$, showing profiles for $\mathrm{H} / \mathrm{D}$ exchange in the toluene methyl and 2-PrOH hydroxyl groups. The kinetic profiles were extracted from the operando ${ }^{13} \mathrm{C}$ MAS-NMR spectra. Each spectrum was acquired with a recycle delay of $60 \mathrm{~s}$ at a MAS rate of $5 \mathrm{kHz}$. The dashed line represents the time at which BPE conversion was first detected. 


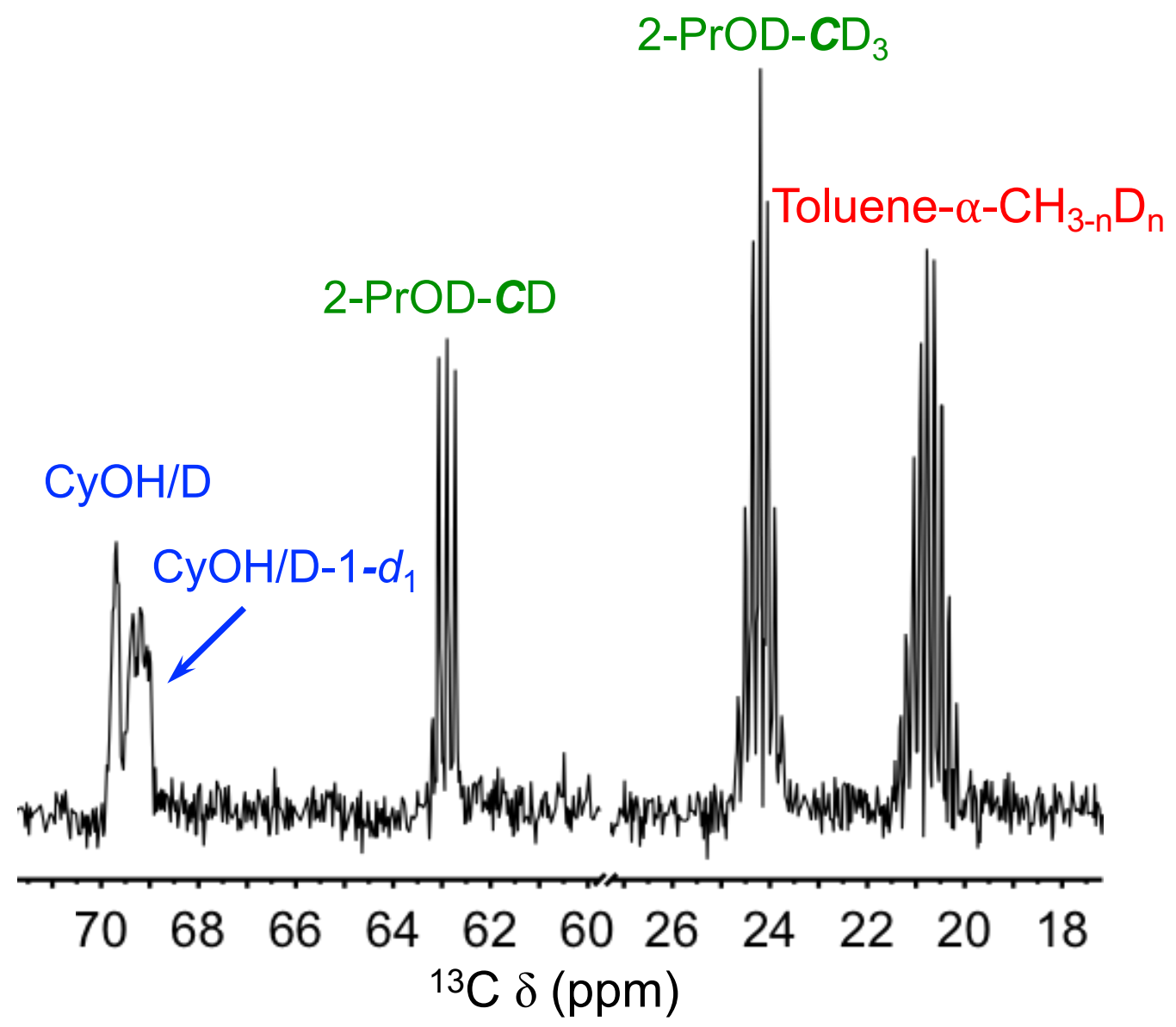

Figure S10. ${ }^{13} \mathrm{C}$ MAS-NMR spectra recorded at $25{ }^{\circ} \mathrm{C}$ after reaction of ${ }^{13} \mathrm{C}$-labeled BPE in 2PrOD- $d_{8}$ with 50 bar $\mathrm{H}_{2}$ (total internal pressure estimated to be 89 bar at $175^{\circ} \mathrm{C}$ ) over $\mathrm{Ni} / \gamma-\mathrm{Al}_{2} \mathrm{O}_{3}$ at $175^{\circ} \mathrm{C}$ in a high $\mathrm{T} / \mathrm{P}$ rotor. Spectra were collected by averaging 16 scans, with a relaxation delay of $60 \mathrm{~s}$. Line broadening of $5 \mathrm{~Hz}$ was applied. Cyclohexanol is denoted as $\mathrm{CyOH}$. 
Table S3. ${ }^{13} \mathrm{C}$ chemical shifts ${ }^{\mathrm{a}}$ for isotopically-labeled toluenes in 2-PrOD- $d_{8}$, extracted from operando MAS-NMR spectra in Figure 6a.

\begin{tabular}{llc}
\hline \multirow{2}{*}{ Species } & \multicolumn{2}{l}{ Chemical shift (ppm) } \\
& $25^{\circ} \mathrm{C}$ & $175^{\circ} \mathrm{C}$ \\
\hline Toluene- $d_{0}$ & 21.4 & 20.6 \\
Toluene- $d_{1}$ & 21.1 & 20.4 \\
Toluene- $d_{2}$ & 20.9 & 20.1 \\
Toluene- $d_{3}$ & 20.6 & 19.8 \\
\hline
\end{tabular}

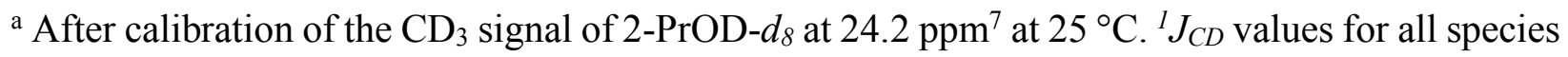
are $c a .18 \mathrm{~Hz}$, at both 25 and $175^{\circ} \mathrm{C}$.

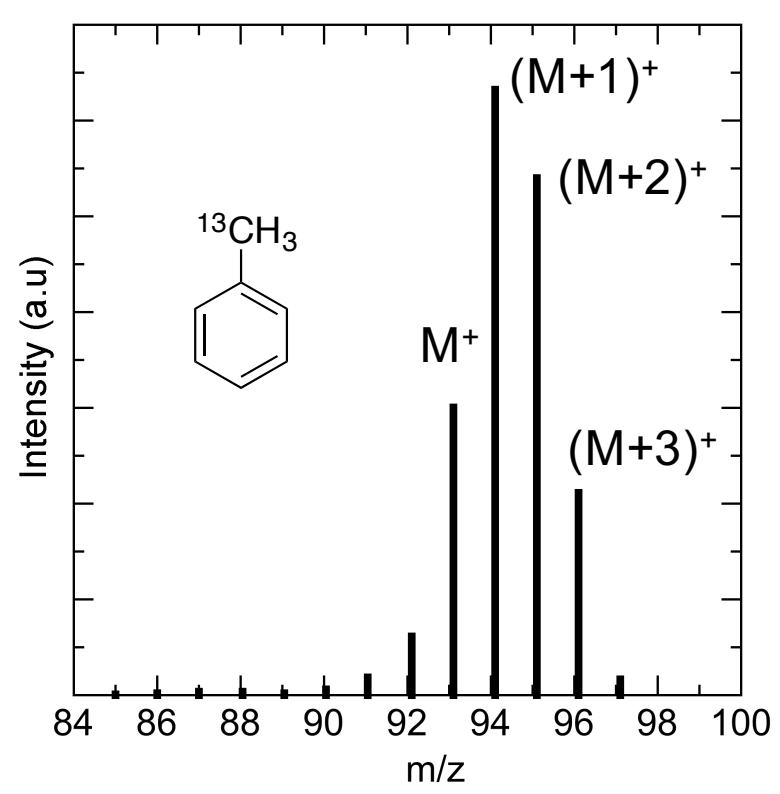

Figure S11. Mass spectrum of toluene ( $\mathrm{m} / \mathrm{z}=93$ for the molecular ion of toluene- $\left.\alpha-{ }^{13} \mathrm{CH}_{3}\right)$, formed by catalytic hydrogenolysis of ${ }^{13} \mathrm{C}$-labeled BPE in 2-PrOD- $d_{8}$ in the presence of $2 \mathrm{wt} \% \mathrm{Ni} / \gamma_{-}-\mathrm{Al}_{2} \mathrm{O}_{3}$ with 50 bar $\mathrm{H}_{2}$ at $150{ }^{\circ} \mathrm{C}$. The aliquot was sampled after $12 \mathrm{~h}$ reaction. 


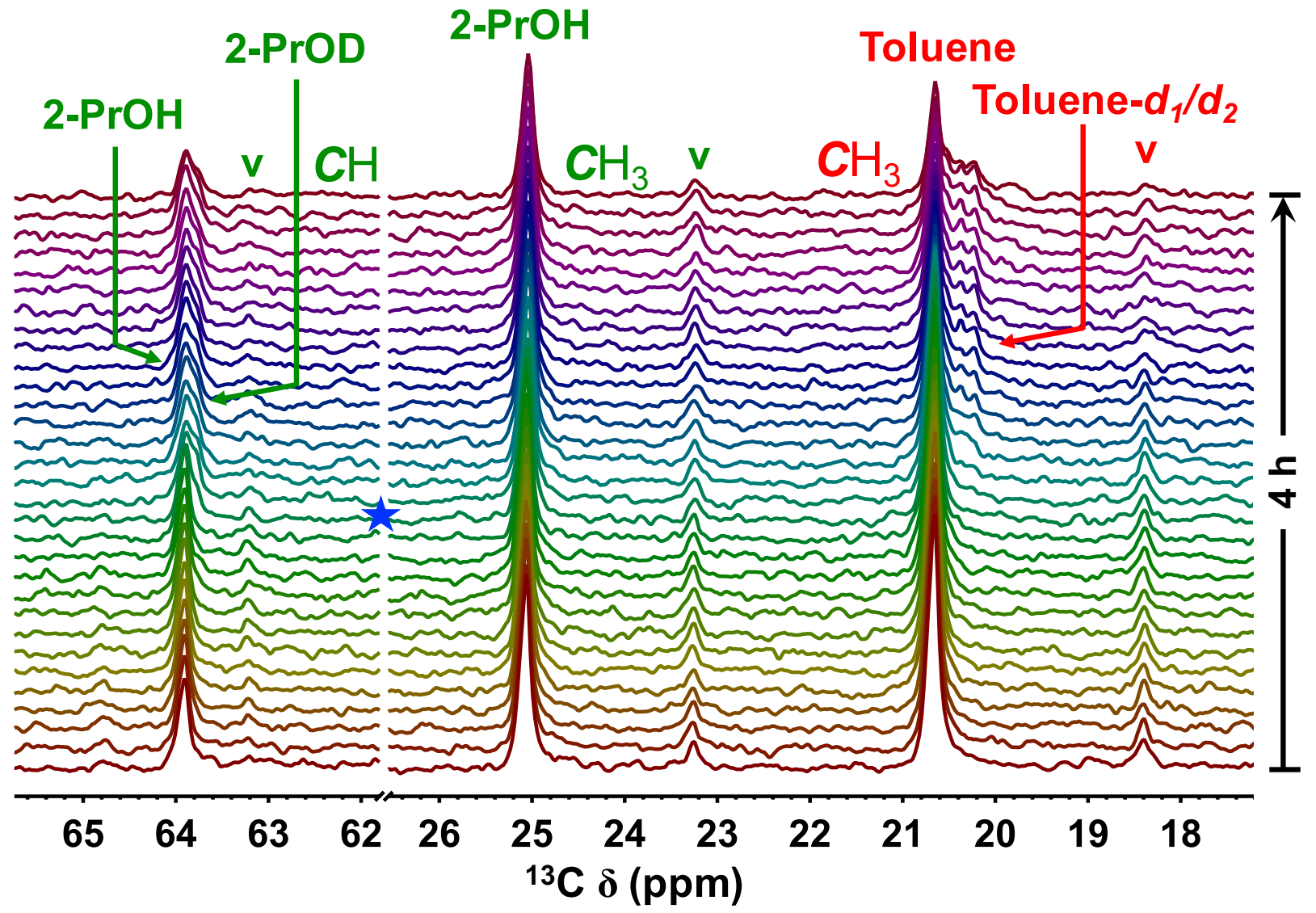

Figure S12. Operando ${ }^{13} \mathrm{C}$ MAS-NMR spectra of toluene- $\alpha-{ }^{13} \mathrm{C}(2.0 \mathrm{mg}, 0.022 \mathrm{mmol})$ in $2-\mathrm{PrOH}$ $(40 \mu \mathrm{L}, 0.52 \mathrm{mmol})$ undergoing exchange with 50 bar $\mathrm{D}_{2}(0.20 \mathrm{mmol})$ catalyzed by air-exposed 2 wt $\% \mathrm{Ni} / \gamma-\mathrm{Al}_{2} \mathrm{O}_{3}(10 \mathrm{mg})$ at $175^{\circ} \mathrm{C}$, showing $\mathrm{H} / \mathrm{D}$ exchange in the toluene methyl and 2-propanol hydroxyl groups. Total internal pressure estimated to be 89 bar at $175{ }^{\circ} \mathrm{C}$. $\star$ denotes the first spectrum at which onset of $\mathrm{H} / \mathrm{D}$ exchange in 2-PrOH and toluene was detected. Each spectrum was acquired with 8 scans and a recycle delay of $60 \mathrm{~s}$. MAS rate: $5 \mathrm{kHz}$. 


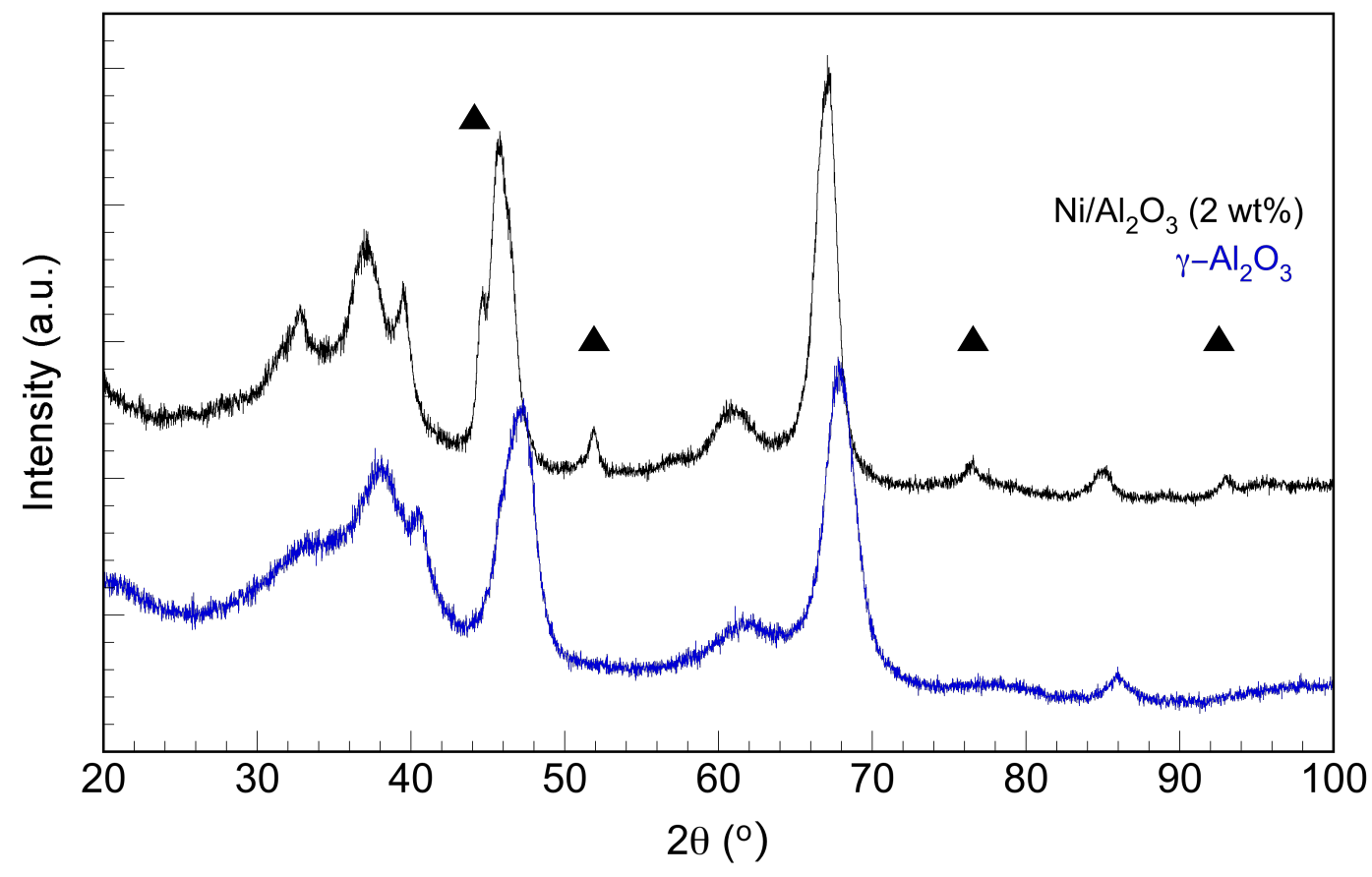

Figure S13. Powder X-ray diffraction patterns of $\mathrm{Ni} / \gamma-\mathrm{Al}_{2} \mathrm{O}_{3}(2 \mathrm{wt} \% \mathrm{Ni})$, after reduction in $\mathrm{H}_{2}$ at $850{ }^{\circ} \mathrm{C}$ and air-exposure at room temperature (black), as well as the $\gamma-\mathrm{Al}_{2} \mathrm{O}_{3}$ support (blue). The locations of the reflections of $f c c-\mathrm{Ni}$ are indicated by triangles. Slight shifts in the positions of the $\gamma-\mathrm{Al}_{2} \mathrm{O}_{3}$ reflections for the reduced catalyst indicate that some (est. ca. $45 \%$, by TPD) of the $\mathrm{Ni}^{2+}$ ions remain associated with the alumina lattice.

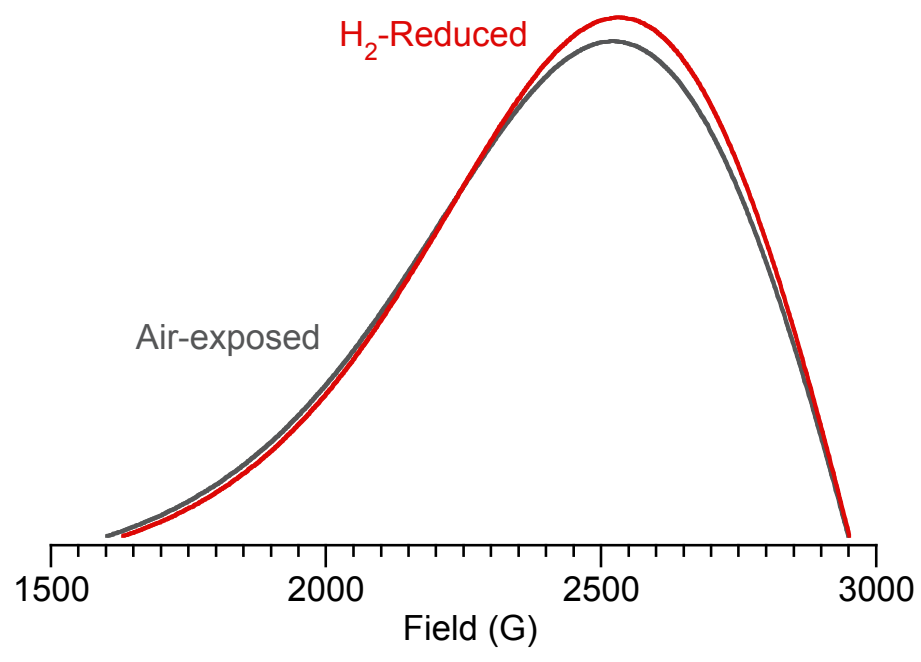

Figure S14. A portion of the room temperature EPR spectrum of reduced $\mathrm{Ni} / \gamma-\mathrm{Al}_{2} \mathrm{O}_{3}$, recorded after $1 \mathrm{~h}$ exposure to air at room temperature (gray), and after its re-reduction in flowing $\mathrm{H}_{2}$ at $170{ }^{\circ} \mathrm{C}$ for $30 \mathrm{~min}$, followed by cooling to room temperature (red). 


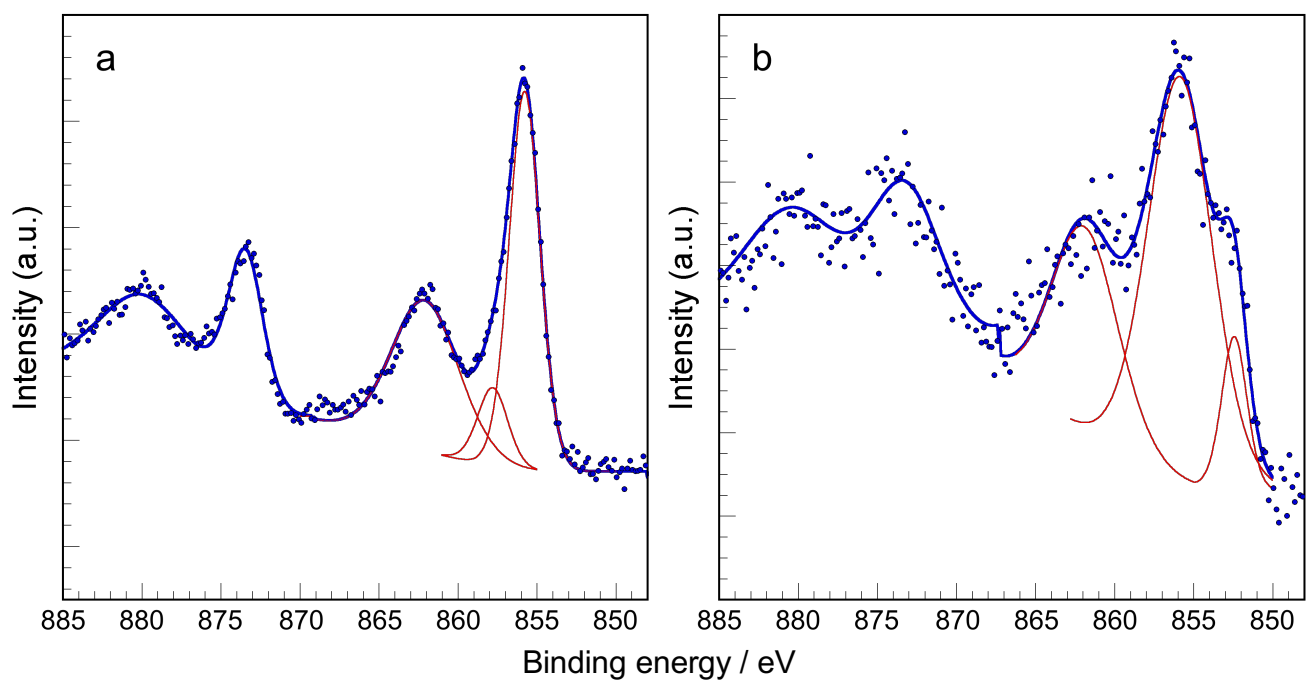

Figure S15. High resolution XPS in the Ni $2 p$ region, for (a) the calcined catalyst precursor, with both $\mathrm{NiAl}_{2} \mathrm{O}_{4}$ and $\mathrm{NiO}$ components, and (b) the $\mathrm{H}_{2}$-reduced catalyst, with both $\mathrm{Ni} / \gamma-\mathrm{Al}_{2} \mathrm{O}_{3}$ and $\mathrm{NiO} / \gamma-\mathrm{Al}_{2} \mathrm{O}_{3}$ components (after air-exposure). The data are represented as blue points; the deconvoluted components are shown as red lines, and the overall fitted spectrum is a blue line. Peak positions and assignments are summarized in Table S2.
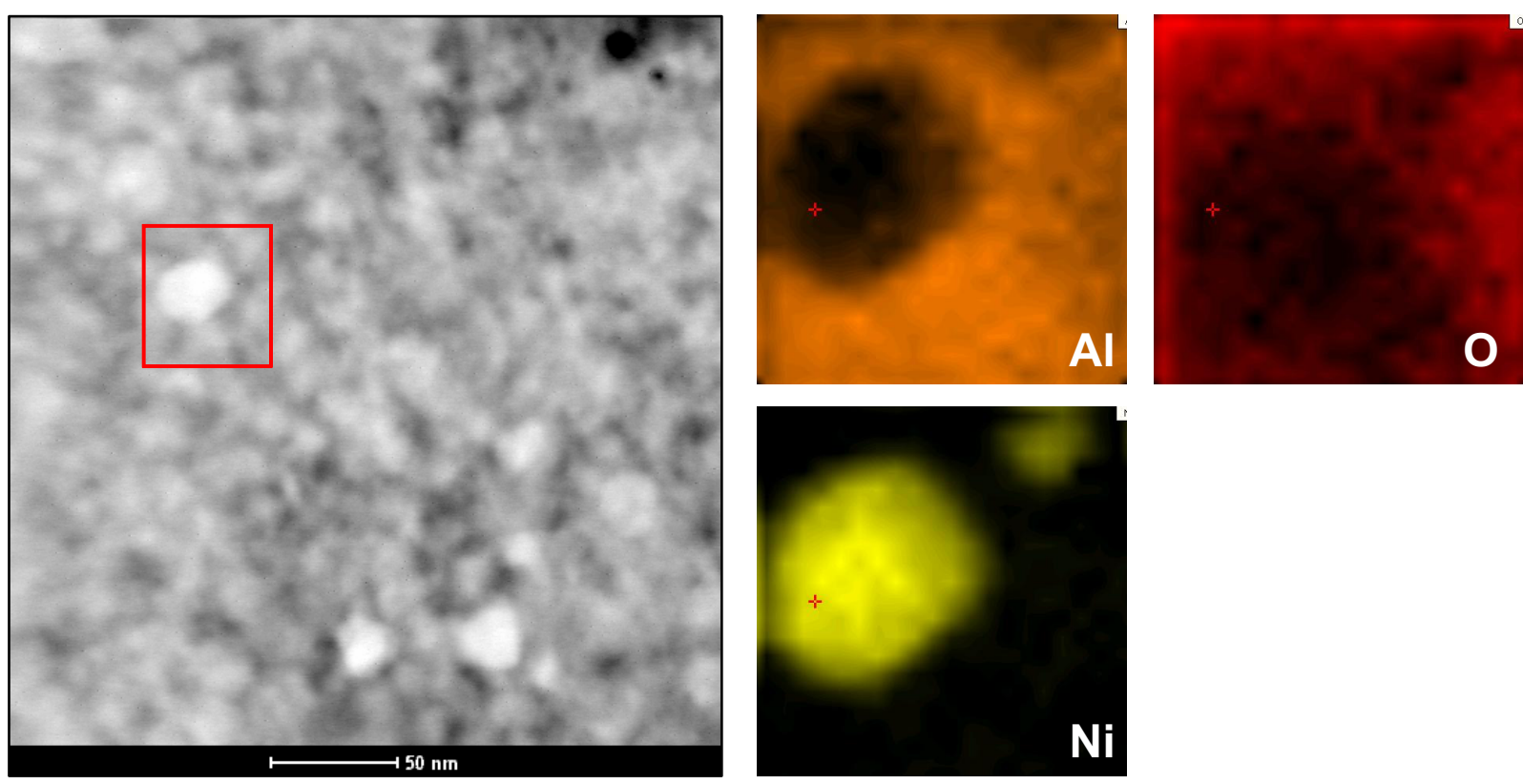

Figure S16. High angle annular dark field scanning transmission electron microscopy (HAADF STEM) image of the $\mathrm{H}_{2}$-reduced catalyst, $\mathrm{Ni} / \mathrm{Al}_{2} \mathrm{O}_{3}$, after air exposure at room temperature. The red square represents the region selected for energy dispersive X-ray (EDX) spectroscopy mapping analysis for the elements Al (orange), $\mathrm{Ni}$ (yellow) and $\mathrm{O}$ (red). Despite the slight displacement of the image, the O EDX image clearly shows a small amount of oxygen superimposed on the Ni nanoparticle location. 


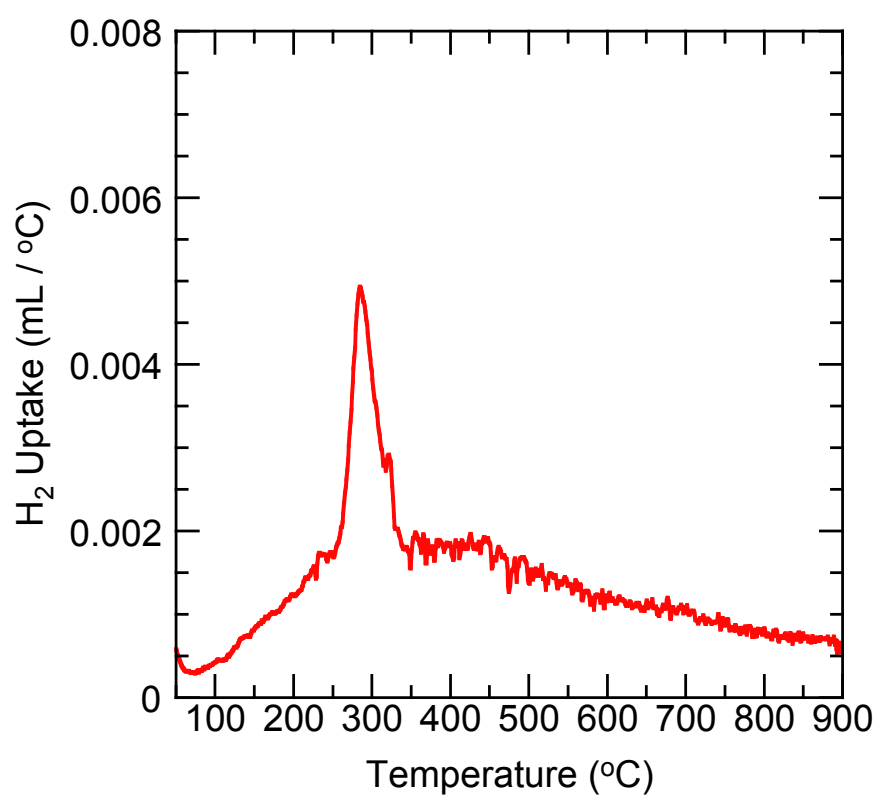

Figure S17. Temperature programmed reduction (TPR) of pre-reduced $2 \mathrm{wt} \% \mathrm{Ni} / \gamma-\mathrm{Al}_{2} \mathrm{O}_{3}(250$ $\mathrm{mg}$ ), recorded after $6 \mathrm{~d}$ exposure to air at room temperature. Integration of the peak centered at $280^{\circ} \mathrm{C}$ yields an area corresponding to ca. $0.12 \mathrm{~mL}$ of $\mathrm{H}_{2}$, which corresponds to reduction of $6.2 \%$ of $\mathrm{Ni}$ atoms in the sample.

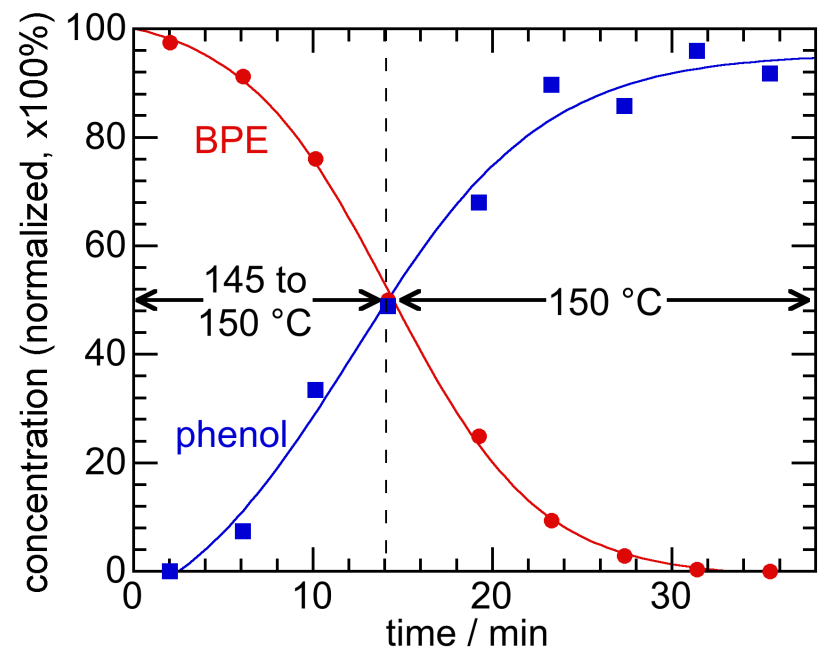

Figure S18. Reaction profiles for BPE hydrogenolysis $(2.0 \mathrm{mg}, 0.011 \mathrm{mmol})$ in 2-PrOH (40 $\mu \mathrm{L}$, $0.52 \mathrm{mmol})$ with 50 bar $\mathrm{H}_{2}(0.20 \mathrm{mmol})$ catalyzed by $\mathrm{H}_{2}$-reduced $\mathrm{Ni} / \gamma-\mathrm{Al}_{2} \mathrm{O}_{3}(2 \mathrm{wt} \% \mathrm{Ni}, 10 \mathrm{mg}$, not air-exposed), measured by operando ${ }^{13} \mathrm{C}$ MAS-NMR. Total internal pressure estimated to be 79 bar at $150^{\circ} \mathrm{C}$. BPE conversion (red circles) and phenol yield (blue squares) were measured while the internal temperature of the NMR rotor rose from ca. $145^{\circ} \mathrm{C}$ (time $=0 \mathrm{~min}$ ) to stabilize at $150{ }^{\circ} \mathrm{C}$ (after ca. $14 \mathrm{~min}$ ). The concentrations of both species were normalized based on the initial intensity of the BPE benzylic resonance (BPE-B). Lines are drawn only to guide the eye. 


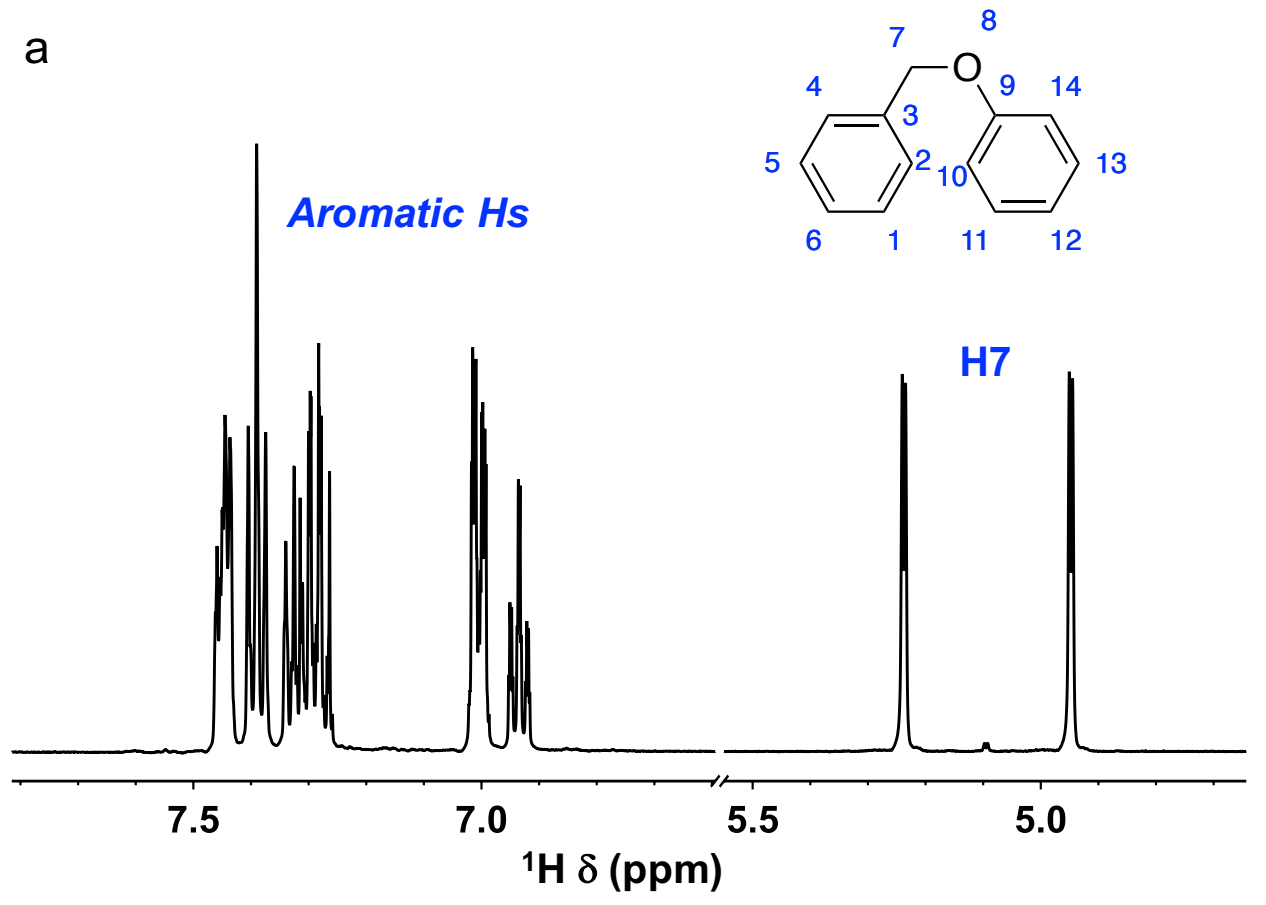

b

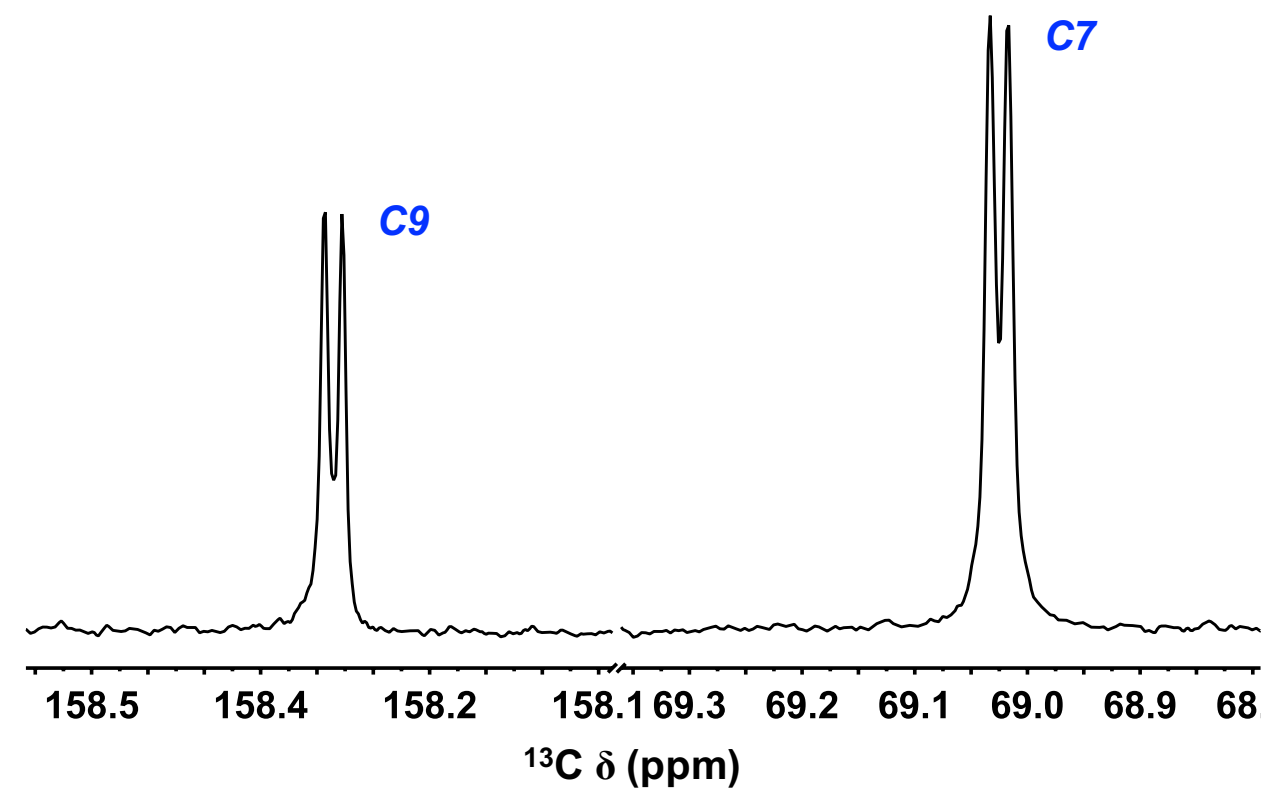

Figure S19. Solution-state NMR spectra of BPE $\left({ }^{13} \mathrm{C}\right.$-labeled at $\mathrm{C} 7$ and $\left.\mathrm{C} 9\right)$, recorded in DMSO$d_{6}$ at $23{ }^{\circ} \mathrm{C}$ : (a) ${ }^{1} \mathrm{H}$ spectrum, acquired at $500 \mathrm{MHz}$ (recycle delay $20 \mathrm{~s}, 16$ scans), and (b) ${ }^{13} \mathrm{C}$ spectrum, acquired at $125 \mathrm{MHz}$ (recycle delay $60 \mathrm{~s}, 16$ scans). 


\section{Additional References}

(1) Tada, S.; Yokoyama, M.; Kikuchi, R.; Haneda, T.; Kameyama, H. N ${ }_{2} \mathrm{O}$ Pulse Titration of $\mathrm{Ni} / \alpha-\mathrm{Al}_{2} \mathrm{O}_{3}$ Catalysts: A New Technique Applicable to Nickel Surface-Area Determination of Nickel-Based Catalysts. J. Phys. Chem. C 2013, 117, 14652.

(2) Wyckoff, R. W. G., Crystal Structures. Interscience Publishers: 1963; Vol. 1.

(3) Legrand, D. L.; Nesbitt, H. W.; Bancroft, G. M. X-ray Photoelectron Spectroscopic Study of a Pristine Millerite (NiS) Surface and the Effect of Air and Water Oxidation. Am. Mineral. 1988, 83, 1256.

(4) Cheng, Z. X.; Zhao, X. G.; Li, J. L.; Zhu, Q. M. Role of Support in $\mathrm{CO}_{2}$ Reforming of $\mathrm{CH}_{4}$ over a Ni $/ \gamma-\mathrm{Al}_{2} \mathrm{O}_{3}$ Catalyst. Appl. Catal. A 2001, 205, 31.

(5) Chen, Y.-G.; Ren, J. Conversion of Methane and Carbon Dioxide into Synthesis Gas over Alumina-Supported Nickel Catalysts. Effect of $\mathrm{Ni}_{-} \mathrm{Al}_{2} \mathrm{O}_{3}$ Interactions. Catal. Lett. 1994, $29,39$.

(6) Mette, K.; Kühl, S.; Tarasov, A.; Willinger, M. G.; Kröhnert, J.; Wrabetz, S.; Trunschke, A.; Scherzer, M.; Girgsdies, F.; Düdder, H.; Kähler, K.; Ortega, K. F.; Muhler, M.; Schlögl, R.; Behrens, M.; Lunkenbein, T. High-Temperature Stable Ni Nanoparticles for the Dry Reforming of Methane. ACS Catal. 2016, 6, 7238.

(7) Kegley, S. E.; Pinhas, A. R., Problems and Solutions in Organometallic Chemistry. University Science Books: 1986. 